\title{
The sociological craft through the lens of theatre
}

\author{
A call for imaginative critical research
}

\begin{abstract}
Since its inception as an academic discipline in the $19^{\text {th }}$ century, sociology has carried an internal tension between the "scientific" and the "hermeneutic" orientations. In response to this tension, the present article reviews important sociological publications that address the art-science dichotomy and explores the relationship between academic sociology and artistic work on society. It takes its departure point from a collaboration between the author and the dramatist Mattias Andersson in the documentary theatre project The mental states of Gothenburg (2006, Angered Theatre). To a large extent, the play's script consisted of extracts of interviews with young people from different parts of the city of Gothenburg. Both "the sociologist", who carried out the interviews, and "the dramatist" ended up as characters on stage. The article especially emphasises the relevance of The sociological imagination by C. Wright Mills (1967[1959]), arguing that through collaborative work with artists, the sociological craft can be further cultivated and thus realise its potential in terms of making well-founded interventions, both in academic discussions and in public conversations.
\end{abstract}

Keywords: sociology, the sociological imagination, arts-based research, documentary theatre, Mattias Andersson

\section{Introduction}

There is an urgent need for imaginative sociological analyses of our present times. The current political conjuncture - characterised by Will Davies (2017[2015]) as a new phase of neoliberalism which is organised around an ethos of punishment and by Wendy Brown (2019) as a time when the hard-right wins elections by promoting ethno-economic nationalism - cannot be unpacked and adequately understood without exploring how individual biographies relate to the historical settings within which they occur. How are the living conditions and the way people make sense of their own lives formed by contemporary political processes? In his seminal work, C. Wright Mills (1967[1959]) presents this as the core task of sociology and declares that the concept of "sociological imagination" enables us to grasp connections between "private troubles" and "public issues" in society. By extension, this helps us to imagine different futures; society could be organised differently, which in turn would enable new life paths and identities. In this article, as I explore the borderland that lies between sociology and 
the arts - using my collaborative work with dramatist Mattias Andersson as a point of departure - I invoke Mills' concept of “sociological imagination” to highlight the fact that many artists, authors, dramatists, film-makers, and photographers who "tell about society" address the same issues and employ similar perspectives as sociologists do (Becker 2007). I argue that scholars have a great deal to gain from paying attention to these individuals and their approaches to their craft, since artistic work is able to communicate ideas in ways that academic articles seldom can. In addition, artistic work with the ambition to intervene in public conversations, such as documentary theatre, has the potential to reach wider audiences. In her opening speech at a Sociological Review conference entitled "Undisciplining: Conversations from the edges", Michaela Benson elaborated on the difference between sociology, defined as "the discipline, the institutional demand and framing of the knowledge that we produce", and the sociological as "something else", "an attitude". Benson claimed that an important function of the sociological lies in its "potential to disturb and challenge the taken-for-granted shape of the discipline". (The speech was later rewritten into a blog post, see Benson 2018). The aim of this article is to use experiences from the collaborative, interviewbased (and hence very "sociological") theatre project The mental states of Gothenburg (2006) to elaborate on how the acknowledgement of sociological work that artists undoubtedly perform enables us to re-imagine academic sociology as a craft and to view the sociologist as a public intellectual.

Since its inception as an academic discipline in the $19^{\text {th }}$ century, sociology has carried an internal tension between the "scientific orientation" and the "hermeneutic attitude" (Lepenies 1988[1985]:1). This tension has sometimes been described in terms of a debate between "the statistically sophisticated survey" on the one side and "the sociological novel" on the other (Halsey 2004:25-26; see also Reed Ariail \& Zald 2014). As a sociologist who works at a Faculty of Humanities, teaching cultural studies and collaborating with "sociological" dramatists, artists, and photographers, I have found a tremendous amount of inspiration in scholarly work that emphasises the value of the borderland demarcated by the above debate. Discussions on the distinction between sociology, as an academic pursuit, and the arts are as old as the discipline itself, especially among sociologists who like myself have felt compelled to explore this creative borderland (Mills 1967[1959]; Nisbet 1976; Berger 1977; Calvino 1986; Lepenies 1988[1985]; Halsey 2004; Back 2007; Becker 2007; Edling \& Rydgren 2011; Bauman \& Mazzeo 2016; Törnqvist 2016). During the past decade, similar issues have also been examined in the growing interdisciplinary field of arts-based research, defined by sociologist Patricia Leavy (2020:4) as "a set of methodological tools used by researchers across the disciplines during any or all phases of research, including data generation, analysis, interpretation, and representation". The term was coined in 1993 by professor of art and education Elliot Eisner, as part of his organisation of a series of small conferences on research guided by aesthetic features. In the field that then emerged, researchers have drawn on the recurrent critique of the art-science dichotomy described above (Barone \& Eisner 2012:ixf, see also; Hesse-Biber \& Leavy 2008; Knowles \& Cole 2008; Liamputtong \& Rumbold 2008; Foster 2016; Denzin 
2019). Having said that, it must be pointed out that arts-based research should not be confused with research-based art (Barone \& Eisner 2012:9).

In the following, I directly engage with this debate by using my work with dramatist Mattias Andersson as a starting point. Our collaboration took place in the context of a documentary theatre project, The mental states of Gothenburg, which dealt with unequal living conditions in the city of Gothenburg. The project was initially inspired by Pierre Bourdieu's study, The weight of the world (1999[1993]). My participation culminated with me and my two colleagues being amalgamated into a character who appeared on stage as "the sociologist", together with my young informants who hailed from different parts of the city. This experience provided me with a unique opportunity to view the sociological craft from a new perspective, and it convinced me that sociological thinking formulated in non-academic settings also possesses value. Below I provide a short presentation of Andersson's play, which is followed by a section where I clarify my views on the relationship between sociology and the arts in the context of several seminal works on this topic. I then reflect on how my participation in the theatre project prompted me to revaluate my academic practices. Throughout this article, I return to my initial claim that there exists an urgent current need for imaginative sociology, both inside and outside academia.

\section{Background: The mental states of Gothenburg}

The mental states of Gothenburg premiered at Angered Theatre (Angereds Teater) in Gothenburg in 2006. Mattias Andersson, a dramatist who had previously written fiction about young people in the urban peripheries of Gothenburg, had been invited by the theatre to write a documentary-based play. Consequently, Andersson contacted a number of researchers whom he knew at the University of Gothenburg's sociology department. When later asked in an interview why it was important for him to find partners outside the world of theatre, he said: "I felt that the project demanded a more scientific, academic approach in order to make visible the working procedure and data collection methods" (Hilton 2015:305). I, a newly-enrolled PhD student at the time, was contracted along with two Master's students in sociology to interview young people from different parts of Gothenburg. ${ }^{1}$ Three of these participants were from the "immigrant-dense" concrete suburbs, three were from the picturesque former working-class neighbourhoods close to the centre, and three were from the well-to-do villa suburbs in the south, near the sea. The interviews took place during the spring of 2006. The main question that Andersson wanted answers to was: "Is there an event in your life that you would like to see acted out on a theatre stage?" We helped design the interview guide, and in addition to this question, our conversations with the young people covered existential themes such as "What is the meaning of life?", "What makes a person into who they are?", and "What does people generally want to achieve here on earth?"

1 Catharina Thörn was part of Andersson's focus group, and the interviews were carried out by Elin Vikström, Rebecka Andrén, and myself. 
During the interviews, my colleagues and I followed the same ethical protocols used in our research at that time (Vetenskapsrådet 2002). We made sure the informants understood that the interviews would be used in a play written by Mattias Andersson and performed by actors at Angered Theatre, that no one else would read the transcript, that they would be anonymised, and that they could at any time cancel their participation or tell us not to use parts of the interview. We also informed them that they would be invited to the premiere. What made the play "sociological", apart from the interview methods, was how the young people's stories were performed against the backdrop of their spatially located socio-economic backgrounds (see extracts from the play on YouTube ${ }^{2}$ ). Unlike participatory theatre projects (e.g. Kaptani \& Yuval-Davies 2008; Erel, Reynolds \& Kaptani 2017), the interviewees were not involved in the scriptwriting or rehearsal process, and unlike "ethnodrama" projects (e.g. Saldaña 2016), the researchers were also not involved in these processes. In retrospect, I sometimes think of this as a lost opportunity; but at the time, this was simply the setup that Andersson outlined and invited us to join. Our agreement to hand over our transcripts to him was a decision based on trust; we knew his work, and appreciated his reflective and thoughtful approach to documentary theatre (cf. Hilton 2015). When performed on stage, a person's story can reach a wider audience than it does in a sociological publication, and we felt assured that Andersson took the responsibility that follows from this seriously.

According to the advertising poster that was used to promote the play, 87 per cent of the play was composed of direct quotations from the interview transcripts, but in the manuscript the young people were given pseudonyms and the exact localities in their accounts were altered. In the autumn of 2006, The mental states of Gothenburg was performed over a few months to an audience consisting of both school classes and paying adults. Ulla Kassius was responsible for the scenography, consisting of chairs lined up in a square where the actors initially sat down together with the audience. It was the first of what would become a long series of interview-based plays by Andersson, of which I was involved in two more ${ }^{3}$. The play has been described as a new start for documentary theatre in Sweden (Arlid 2021).

2 This film was produced by the author for a presentation of an early version of the present article at the Sociological Review conference "Undisciplining: Conversations from the edges", 18-21 June 2018. It was then published on YouTube by The Sociological Review: https://www.youtube.com/ watch?v=TOMv8FtpkbY (Accessed 31 August 2021).

3 Gangs of Gothenburg (Backa Teater, 2009), Utopia 2012 (Backa Teater, 2012*), The mental states of Sweden (Dramaten, 2013*), Acts of goodness (Backa Teater, 2015), The misfits (Backa Teater, 2016), Vi som fick leva om våra liv (Backa Teater, Dramaten, 2019). ${ }^{*}=$ I coordinated the interviews. 


\section{The relationship between sociology and the arts}

A close review of the literature on the rewarding relationship between sociology and the arts reveals three distinct and basic positions. To illustrate these positions, I refer to six sociological publications that inform the theoretical framework used in my analysis. Robert Nisbet's classic book, Sociology as an art form (1976), is the most famous work on this topic and constitutes one extreme position. Nisbet argues that the difference between sociology and arts is insignificant. Recent writing on arts-based research also approaches this point of view. For example, in the introduction to her book Method meets art: Arts-based research practices, Patricia Leavy (2020:3) describes how many researchers enter this field with a longing to "merge their scholar-self to their artist-self". In theory, the other extreme position would be to state that sociology and art are essentially different and should be kept apart. However, on such a continuum, Sociological insights of great thinkers: Sociology through literature, philosophy, and science would rather be placed in the middle. In this book, Christoffer Edling and Jens Rydgren (2011) argue that literature can illustrate sociological theories and concepts and inspire sociologists. Found between these two actual positions, we have C. Wright Mills' The sociological imagination (1967[1959]), Les Back's The art of listening (2007), and Howard Becker's Telling about society (2007). Work on the topic by Zygmunt Bauman and Riccardo Mazzeo (2016), Stuart Hall (interviewed by Back 2009), and Maria Törnqvist (2016) can also be ascribed to this position. While none of the latter scholars explicitly equate sociology with the arts, they all emphasise the value of "the sociological", and seek out dialogue with artists more enthusiastically than do Edling and Rydgren. Referring chiefly to these publications (and primarily to Mills' book), in the following section I clarify my position with regard to the relationship between sociology and the arts. I do this by focusing on three recurrent themes that can be found in the literature.

\section{Theme I: Imagination at the core of sociology}

The most prominent theme in work done on sociology and the arts is the concern that the academic discipline of sociology might lose its soul if its relationship with the arts is delineated too clearly. As early as 1919, Max Weber argued in Science as a vocation (1946[1919]:136) that we must not forget that the foundation of all of the sciences, including the social sciences, is imagination. He claimed that "[i]deas occur to us when they please, not when it pleases us" and emphasised the importance of combining systematic work and enthusiasm. A hundred years later, Leavy (2020:19) underlined how both art and social research require flexibility and intuition, and "result in the communication of information from which an audience generates meaning". Chronologically in between these works, Nisbet's Sociology as an art form (first written as a presidential address for the annual meeting of the Pacific Sociological Association in 1962, and then published as a book in 1976), he argued that sociology is one of the sciences, but is also nourished by the same kind of creativity as the arts. Nisbet further noted that until the nineteenth century, science and the arts were not 
generally considered to be distinct and separate areas, illustrating his argument with references to the work of Kepler and Michelangelo (Nisbet 1976:9; see also Lepenies 1988 [1985]; Halsey 2004; Swedberg 2014). Nisbet (1976:4) described his own work as a kind of prophylactic against the evils of scientism, which is "science with the spirit of discovery and creation left out", and concluded that if Marx, Weber, Durkheim, and Simmel had adhered to the instructions on research design, methodology, and theory construction that were taught at sociology departments in the 1960s, "the world of thought would be much poorer" (ibid.:7). Today, it would probably make sense to add Bauman to this list of scholars, as he is often described in terms of "a poet-intellectual" and "an accomplished sociological storyteller" (Jacobsen \& Marshman 2008). Unsurprisingly, one of his last books closely examined the relationship between sociology and literature in action. Bauman and Mazzeo (2016:799) argued that since the first of these two "types of inquiry into the human condition" is classified as a science and the other as one of the arts, more energy has been put into drawing boundaries between the two than building bridges between them (cf. Bauman, Jacobsen \& Tester 2016:14-15). The present article can be considered as an attempt to perform the latter project. This ambition is also expressed by Leavy (2020:319), who argues that the fusion of artistic and scientific methods makes us better equipped to address the complex realities of social life. In addition to the aim expressed in the introduction above, my hope is that this article will introduce such perspectives to a broader number of Swedish sociologists.

In The sociological imagination, Mills (1967[1959]) raises concerns similar to Nisbet's with respect to certain developments within American sociology. Mills refers to the dominance, on the one hand, of "grand theory" (referring to Talcott Parsons' structural functionalism), and, on the other hand, to "abstracted empiricism" (including standardised data collection, i.e., the mere compilation of data and not an analysis proper). Against this backdrop, Mills argues that it is important to nurture the creative spirit that constitutes the core of the discipline. The relationship between sociology and the arts has been further examined by a contemporary sociologist Maria Törnqvist (2016:313) who reminds us that the words theory and theatre share the same etymological origins. She suggests that Mills' concept of a "sociological imagination" can be understood as a specific orientation, essentially related to the intuition that characterises artistic work. Through the practice of sociology, this intuitive knowledge becomes embodied (ibid.:308). I consider this a crucial part of the sociological craft.

As reported above, the conversation around sociology's relationship to the arts has been relatively constant throughout the history of the discipline. In a very different context than Nisbet and Mills, the British sociologist Les Back proposes in The art of listening (2007) that the aim of "sociological listening" is to avoid instrumental and formalised research approaches in favour of a more patient and curious way of doing sociology: 
So, sociological listening is not just about transcription, or just emptying people of their expertise and wisdom. [...] It is not only about listening to one specific voice. It involves artfulness precisely because it isn't self-evident but a form of openness to others that needs to be crafted, a listening for the background and the half muted. (Back 2007:8)

Back primarily refers to Mills (1967[1959]) in his work, but argues that the spatial scale has been transformed over the 40 years that have passed since the publication of The sociological imagination. He further proposes that in order to make sense of contemporary migration processes, we need a global sociological imagination so that we can "prise open the public issues in these private troubles" (Back 2007:11; cf. Puwar \& Sharma 2012). It is worth noting that, today, "private troubles" are shared globally through social media, and public issues are rarely confined to the national level.

In Telling about society, Becker (2007:xi) describes how he found as much inspiration in fiction, drama, film, and photography as in the sociological publications he was "supposed" to read. Regardless of their conclusions, something that all of the sociologists presented above have in common is openness towards non-academic societal depictions. Their lists of references are not exclusively academic, for example. One piece of advice that Back offers to PhD students in this area is to "Read inside your discipline and outside it. Read popular articles, novels, poetry" (Back 2007:174; cf. Leavy 2020:307-308). This agrees with Mills' (1967[1959]:18) observation: "In the absence of an adequate social science, critics and novelists, dramatists and poets have been the major, and often the only, formulators of private troubles and even public issues". Much like art, sociology depends on the practitioner's imagination, and in order to nurture this ability we need to look for and embrace "the sociological" in the arts (Benson 2018). This article offers an illustration of how collaborating with a dramatist made me revaluate my sociological practice.

\section{Theme II: The sociologist as a public intellectual}

Nisbet argued that important sociological work is always "written in response to a single, compelling intellectual problem, or challenge provided by the immediate intellectual environment" (Nisbet 1976:20). Like Mills, he was reacting to the development of sociology in the U.S. in the post-war era. With respect to methodology, Mills was worried that "abstracted empiricism" prevented research into the significant human issues of the time, with such methodology being tied up in irrelevant details (Mills 1967[1959]:72). Concerning theory, Mills claimed that Parsons was so possessed by the idea of constructing a universal model that he [Parsons] did not care that such a model could not be used to understand any specific social problem (ibid.:48). Writing this in a very different context, I share Mills' concerns; if too few sociologists elaborate on current public issues and take part in public conversations, the discipline risks becoming politically irrelevant in the present. As social research is today increasingly accused of being "politicised", scholars might for understandable reasons hesitate to focus on heavily-debated topics in their work. In this article, however, I argue that we need to find ways to do just that. 
Mills does not promote activism, but warns against working in time-restricted "projects" where the problem, research questions, theoretical perspective, and method are pre-determined at the project's inception. To counter this approach, he delineates an image of the "intellectual craftsman" [sic] who is in possession of a notebook:

What this means is that you must learn to use your life experience in your intellectual work: continually to examine and interpret it. In this sense craftsmanship is the center of yourself and you are personally involved in every intellectual product upon which you work. (Mills 1967[1959]:196)

Back (2007:172) refers to Mills on this topic, and advises his students to follow their own interests and always "keep a ledger of your thinking". Notwithstanding this similarity, it is evident that these two scholars were addressing students from very different times. Mills would, I suspect, be somewhat distressed by the fact that our increasingly neoliberal university system is run in accordance with New Public Management principles (cf. Brown 2015). As a teacher in contemporary academia, it is challenging to argue for the importance of developing a sociological imagination. Since few predictable employment pathways with this focus are presented to graduates of the social sciences or liberal arts, these educational endeavours are too often perceived by students as "insecure investments" (ibid.:180-181). However, in the scholarly work that I draw on here, I have found some words of encouragement to communicate the value of any interventions that such sociological imagination may enable. For example, in his call for "counterfactual theorizing", Roland Paulsen (2014:182) draws on Mills to emphasise the fundamental democratic importance of imagining different futures beyond capitalism.

Approaches that view the sociologist as a public intellectual form part of why sociologists interested in the borderland between sociology and the arts, like myself, are often inspired by cultural studies (cf. Back 2007; Carrington 2017). During an interview where he discussed what constituted the core of cultural studies in Birmingham the 1970s, Stuart Hall emphasised the fact that it was never about "high theory". Looking back, Hall noted that all of his publications were political interventions of a kind: "It may not be about politics explicitly, but it is trying to shift the terms of the debate, intervene on one side or another, clarify something, wipe some other distorting view out of place so that something else can come through" (Back \& Hall 2009:663). However, much like in documentary theatre, there is a tension in qualitative sociology between "giving voice" to unheard people and making political interventions (cf. Arlid 2021). Back (2007:20) emphasises that the value of sociology lies in its time-consuming practice. Sociological listening is always informed by theory, but does not have the aim of illustrating already-formulated arguments. In the early years, the discipline of cultural studies could to a large extent be characterised as sociology practised by scholars in the humanities (Lepenies 1988[1985]:195). Today, arts-based research attracts sociologists who possess a similar ambition as Hall to address social injustice issues and to make interventions outside of academia (e.g. Foster 2016; Denzin 2019). As public 
intellectuals, what sociologists have to offer is findings from elaborative research, both published and ongoing.

\section{Theme III: Towards an artful sociology}

Becker (2007) does not consider all work on society to be sociology per se, but rather states that artistic representations of society complement academic studies, thereby allowing us to see things that we would have otherwise missed (Becker 2007:6f; cf. Benson 2018; Leavy 2020). Invoking a similar argument, Bauman and Mazzeo (2016:93) write:

Asking [...] fundamental existential questions, and bringing them back to the public agenda, are the vocations shared by literature and sociology. Pursuit of these questions unites the two creative pursuits - renders them complementary and sentenced to perpetual interaction and mutual inspiration.

In this context, Edling and Rydgren's (2011) position is essentially the same as that taken up by Mills, Bauman, Becker, and Back - and myself. Firstly, we all agree that sociological research needs to be carried out by someone with a degree in sociology or possibly another social science discipline. This is the case because sociological research is a craft, and to perform a craft, one needs training. Moreover, these scholars all provide definitions of what distinguishes sociology as an academic discipline. For instance, Mills (1967[1959];18) argues that, compared to the arts, sociology can offer the necessary intellectual clarity that is needed to formulate questions containing both private troubles and public issues. Edling and Rydgren do not, however, elaborate on the prospect of collaborating with artists. In their work, sociology and literature appear as related but parallel activities that can find inspiration in each other (see also Malmqvist 2017). For these reasons, I position myself closer to Mills, Becker, and Back. Without undermining the academic aspirations of the discipline, I argue for the practice of a more artful sociology.

In contrast to the scholars mentioned above, Nisbet does not have much to say about what distinguishes sociology from the arts. In Sociology as an art form, his aim is to argue against such claims. Referring to Thomas Kuhn and Karl Mannheim, he writes that distinctive themes and styles have been addressed in the arts and in sociology throughout history (Nisbet 1976:40). In the introduction of her book on arts-based research, Leavy (2020:2) describes how it was only when she wrote a novel based on her data that she actually reached an audience and felt that her work made an impact. It is often argued that the sociologist has to work within the confines of empirically identifiable facts, but Törnqvist (2016:13) asks whether she is not also a kind of poet. She has developed a concept of sociology that works not just through literature, but also as literature (ibid.:7). This is illustrated by Yasmin Gunaratnam's research project on palliative care, older people, and ethnicity, which included the writing of a series of poems based on interviews with her research participants. However, while Leavy's motive for writing a novel was to reach a wider audience, Gunaratnam adopted her 
particular approach as a way to fulfil her obligations to her research participants and "to the density of their stories and to the meanings of their lives and deaths" (Gunaratnam 2007:284; cf. Puwar \& Sharma 2012). Returning to the three basic positions that I identified earlier, I presume that scholars who consider the difference between sociology and art as insignificant would not object to this type of work. Conversely, scholars who argue that these fields need to be kept apart, or who see them as parallel activities that can possibly find inspiration in each other, would probably not endorse such an approach. For Edling and Rydgren (2015:10), sociological imagination does not encompass artistry, but, instead, refers to a creative mode that all sociologists need, regardless of their methodological or theoretical preferences. As stated above, in this article I argue for a middle position that acknowledges the genuine need to communicate our sociological research findings to a wider audience.

"Academic writing" is a recurrent topic in discussions of routes toward a more artful sociology. This theme needs to be understood in the context of the abovementioned tension within sociology between what might be characterised as a "scientific orientation" and a "hermeneutic attitude" (Lepenies 1988[1985]:1), where the former is marked by a more formal and sometimes more bureaucratic use of language than the latter. According to Mills, who clearly positions himself in this debate, sociologists need to avoid "socspeak", because writing intelligibly is a precondition to being read, and that ultimately needs to be our goal. He notes that writing for a wider audience does not reduce the sociologist to the level of being a "mere journalist" (Mills 1967[1959]:218). The quality of a sociological analysis should be evaluated with the same criteria regardless of the style of writing. We need to trust in the sociological craft and our arguments, or, as Mills puts it: "to overcome the academic prose you have first to overcome the academic pose" (ibid.:219-222; see also Billig 2013). This issue has come to a head in contemporary academia. Today, our thinking is caught up in one strictly regulated form-the academic article (cf. Törnqvist 2016:310). Publishing in English in international journals has almost become the definition of "being scientific", thus entailing that any sociological analysis presented in a different form - or in nonEnglish scholars' first languages - runs the risk of being devalued. We need to resist this development, both in our research and in our teaching. Being a "writer" is not necessarily how sociology students come to think of themselves, which explains why the seventh point on Back's (2007:177) list of advice to PhD students is to "embrace writing as a challenge". Leavy (2020:xiv) does not suggest that we abandon the academic article, but instead that we explore the different shapes our research can take, in ways beyond just looking at the style of writing. I am sympathetic to this approach, but feel there is also a need to respect the artistic crafts. This is why I, like many other sociologists without artistic training or experience, take on such exploration in collaboration with artists rather than by myself. 


\section{New perspectives on the sociological craft}

Drawing on the discussion above, I will use my experience of the theatre project The mental states of Gothenburg to highlight how such collaborative projects can enable sociologists to reimagine the purpose and potential of our discipline. In an essay on Mattias Andersson's productions, literary scholar Tomas Forser (2015:260) defines his work as "theatre sociology". When theatre critic Johan Hilton (2019) listed a number of interesting theatre premieres in the autumn of 2019 and included Andersson's new play Vi som fick leva om varra liv (We who lived our lives over), he rhetorically asked whether it was not time for the University of Gothenburg to make Andersson an honorary professor in sociology. The documentary method that was first developed in the play The mental states of Gothenburg has, to a large extent, defined Andersson's career up until the present time (Forser 2015; Scenpodden 2019). Moreover, this method - which in an academic setting might have been characterised as ethnodrama, a stage play based on ethnographic data (e.g. Saldaña 2016) - has also profoundly affected my own career. In this section, I refer to this project as I elaborate on what we can learn about sociology by comparing it to - and sometimes working with - other ways of representing society. Initially, I discuss what artists might gain from such collaborations. Doing so has facilitated my identification of certain aspects of the sociological craft.

\section{The role of "the sociologist" and "the academic pose"}

In the theatre project The mental states of Gothenburg, "the sociologist" functioned on two distinct levels. Firstly, this person (i.e., my two colleagues and myself) worked as a representative of the university, thereby lending the production a certain legitimacy. Secondly, "the sociologist" was included as a character in the play. The poster that was used to advertise the play included an extract from the script covering a fictional scene set in Angered Theatre's office. In this scene, Andersson, as a character in the play, worries about his relationships with the young people on whose stories his play is based:
[...] and I mean, I have nothing to hide. I'm not cheating anyone; everyone knows what it's about and the sociologists think it is completely ethically correct. At the same time, a situation can arise, I don't know, regarding money, or whose words they are really and all that, you never know, and I gave everyone a letter with my mobile number and email address and "if you want to be anonymous or if you want to take back something you've said, contact me" and all that, I have been completely open [...] (Quotation from a promotional poster for The mental states of Gothenburg).

The play opens and closes with acts in which the young people's stories are central to the development of the play. Between these acts, the audience views a fictive act that presents the stressed out and agonised dramatist. This approach provides an overall effect of a theatre performance which includes a chapter on methodology (see YouTube URL in footnote 2). I do not believe that, before the project started, Andersson ima- 
gined that research ethics would be one of the main themes of the play. However, I found it very exciting that he felt it necessary to introduce this meta-discussion into the play during his work on the manuscript. A person who makes use of interviews is necessarily confronted with the ethical implications of doing so, whether they are a sociologist or a dramatist.

In a recent interview Andersson gave that touched on how the genre of "documentary theatre" has grown over the last decade, he claimed that his methodological transparency distinguishes his work from other work in this genre. He indicated that he has a problem with documentary plays that do not provide the audience with any information on how the empirical material that is portrayed in the play was either produced or discovered. To this point, Andersson asks the following questions: "What questions were asked and who conducted the interviews? Who picked the interviewees? Did someone actually say this, or is it a trick? Is there a voice of an author present in the play and how much of the material is manipulated?" (Hilton 2015:316). Qualitative research is not always the congenial activity that it is sometimes described as (e.g. Mulinari 2003), and each person who is engaged in ethnographic fieldwork must address the power relations that such work entails. Researchers who employ qualitative methods can offer advice to artists who wish to use the life stories of real people in their work. In their critique of increasingly standardised research processes, Nisbet (1976) and Mills (1967[1959]) both identified methodology courses as "problematic". However, in my more recent experience, courses of this type offer us the opportunity to immerse ourselves in 50 years of conversations on reflectivity and ethics. Such training is not, to my knowledge, generally provided at art school. Today, methodological literature on arts-based research expands upon many of the themes addressed in this article. Leavy (2008:352) argues that the genre of ethnodrama does not just offer new ways of presenting ethnographic data, but, just as importantly, is a new way of exploring it. For this reason, in a possible future collaborative theatre project I would find it interesting to take part in some way in the processes of script writing and rehearsals.

I suggest that what Andersson primarily gained by working with "real" empirical material was not merely a series of authentic biographical narratives, even if some of them were pretty astounding. He had written similar fictional stories before. Instead, he was provided with examples of natural spoken language and meandering narrative structures (cf. Scenpodden 2019; Arlid 2021). Moreover, the empirical material enabled him to better address issues regarding the representation of urban inequality. Consequently, not just the sociologist but also the dramatist himself ended up on stage. In the play, the sociologist is not a person with whom the audience can easily identify, but serves as a foil to the power relationship that is part and parcel of qualitative sociological practices. This was achieved by letting the young people whom she interviews show their resistance to everything she represents (i.e., the Establishment) with crossed arms and sceptical, squinting eyes. On stage, they show great reluctance when replying to her questions (see YouTube URL in footnote 2). This does not accurately resemble my own fieldwork experiences, and to be represented like this was a rather uncomfortable experience. However, portraying the sociologist - and himself - in this way enabled 
Andersson to address research ethics head-on. Some of the questions about family relationships probably seemed quite intrusive to the audience - and, indeed, they were.

Throughout the theatre project, I came to consider sociology as an activity that is much more similar to the production of literature, art, and drama than I did as an undergraduate or, for that matter, as a postgraduate student. Conversely, it was important for Andersson to portray the sociologist as a representative of science. Before I became involved in his follow-up projects, namely Utopia 2012 (2012) and The mental states of Sweden (2013), I moved from the Department of Sociology to the Department of Cultural Sciences. Once again, my task was to coordinate the interviews that produced the empirical material used in these projects. On these occasions, I involved Master's and $\mathrm{PhD}$ students not just from the field of sociology but also from ethnology, cultural studies, and film studies. Notwithstanding this diversity of academic fields, Andersson consistently referred to this academic collective as "the sociologist" in his manuscripts, since this was an important character in his plays that could not be readily replaced by "the culture studies scholar". My impression is that there was also an aesthetic dimension of Andersson's wish to keep the rigorous sociologist as a character in his work, including her [my] cardigan and her [my] tape recorder. Whatever we might feel about this, "the sociologist" represents science to a much larger extent than one might initially assume. Paradoxically enough, as a character she corresponds to "the academic pose" (Mills 1967[1959]:219) that I argue against in this article, drawing from my experiences of our collaboration. In order to highlight the power relation between the sociologist and the young people - and probably to some degree to entertain - Andersson made her into something of a caricature. Notwithstanding this, in interviews he always presented the sociologists as indispensable for the project (e.g. Scenpodden 2019), and his artistry is still strongly associated with the discipline.

\section{"Telling about society" in sociology and documentary theatre}

Mattias Andersson was impressed by the wide range of topics raised during the interviews, and later claimed that he was completely open to using whatever issues came up during these interviews (Scenpodden 2019). Regardless of this claim, it remains my impression that he already had a basic idea of what story he wanted to tell from the very start. As a dramatist, Andersson was of course free to create the characters that he needed to tell his story. The audience of his work met the young characters in their roles as representatives of the three different parts of the city where they lived. During the interviews, the young people had shared stories that transcended the differences which informed the motives behind the original selection of the participants - for instance, about mothers with cancer - but only a few of these parts of the transcripts were actually used in Andersson's manuscript. At first, I interpreted his vantage point as artistic, but I gradually realised that his position was not essentially different from how sociologists initially approach a research topic. The impossibility of conducting purely inductive inquiries and the importance of self-reflection with respect to one's pre-understandings have been recurrent themes in debates on urban ethnography during the last few decades (e.g. Wacquant 2002; Duneier 2002). The mental states 
of Gothenburg is a story of a segregated city where young people's experiences are, to a high degree, determined by where they grow up and live their lives. In my opinion, the most complex characters who appear in the play are the young people who hail from the deprived suburbs, while the characters from the middle-class and well-off areas are used in a number of scenes as foils to contrast against the residents from the impoverished areas of the city. Stories of an injured knee (and hence a ruined football career) and constantly arguing parents easily appear as banal when portrayed alongside stories of sexual assault and domestic violence. However, against the backdrop of a contemporary public debate where marginalised youths are so often dehumanised (e.g. Dikeç 2018), I found that there was good motivation for this move employed by Andersson. This is even more true today, when the "grievability" (Butler 2009) of the lives lost in "gang wars" is regularly brought into question. As sociologists we need to study both "up" and "down" (e.g. Nader 1972), but I argue that at this moment it is urgent to listen to these voices (cf. Bassel 2017:5). When I claim that there is a great need for imaginative sociology in our present time, this type of drama is an example of what I call for. While it may be the case that analyses connecting a person's struggles in life - and even criminality - with social structures and contemporary political processes are sometimes rejected as mere "sociological justifications", as then Mayor of London Boris Johnson did after the riots in 2011 (BBC News 2011; see also Slater 2011), as sociologists we must insist that coming to a particular understanding of an event or a social phenomenon could not be equated with a defence of the people involved in it. Our task, Back (2007:17) argues, is to bring to life the people whose experiences are being analysed. In The mental states of Gothenburg, Andersson did just that with the marginalised youth. As a dramatist he had the artistic freedom to make one of them the "star" of the play - and this person's story was also included in The mental states of Sweden seven years later - but in ethnographic work, too, more focus is often put on some participants than on others. In crafted sociology, the reason that certain stories are highlighted is not that they confirm the "political" agenda of the researcher, but rather that these private troubles are more intriguing to theoretically elaborate on in relation to public issues.

During my collaboration with Andersson, I realised that I also create characters in my own work as a sociologist who works with ethnographic methods. Sometimes, I use pseudonyms and place participants in relation to each other in ways that help me present the argument that I developed through my analysis of transcripts and field notes. I had just never thought about the nature of my work in such terms. This confirms Nisbet's (1976:4) argument about "scientism" and how this development of the sociological craft (by comparing it to how writers, artists, and dramatists "tell about society") is usually not part of our training. However, this state of affairs is something that the sociologists whose work I have presented above want to change. Some time into the rehearsals of The mental states of Gothenburg, Andersson asked for the tape recordings of the interviews. Later, when I asked him whether they had been of any help to him, he explained that by that stage the ensemble had already used the transcripts to sketch out the characters, and they did not get much use out of the tapes. 
We may ask how a sociological study is any different from writing a play in this respect. In an academic article, a person can be presented in a number of different ways, even if the transcribed interview is quoted, depending on how the text is edited regarding spoken language, repetitions, and hesitations. On stage it is a matter of tone of voice, body language, interaction, props, and so on.

As soon as my two colleagues and I left the première of The mental states of Gothenburg, we began discussing how the characters that Andersson had created resembled our impression of the interviewees. As sociologists, we are used to having complete control over our material. Sometimes, we talk unreflectingly about "our" interview subjects, implying that we have the sole right to interpret what they tell us. Nevertheless, many sociologists hesitate to let people comment on the analyses of what they say. The experience of seeing "our" young people become characters on stage was not an entirely pleasant one. In this context, who has the right of interpretation becomes an essential issue. However, how could I presume that I could have portrayed them in a more truthful way by my use of various sociological tools? The step from transcript to theatre manuscript might, on the one hand, be larger than the steps taken via traditional sociological analysis, but in none of these cases are we just "giving voice" to someone or merely "telling her or his story" (e.g. Marander-Eklund \& Östman 2011). On the other hand, there is a high probability that it is easier for people to imagine a stage play based on their stories than an academic article that analyses them, and hence to decide what they want to share in the interview. These insights enable us to reflect on how we might more closely involve our research participants in our analyses. When arts-based research emerged in the 1990s, it grew out of decolonising efforts within the qualitative paradigm, where the power within the knowledge-building process was re-examined in order to avoid creating knowledge that resulted in the continued oppression of minority groups (Leavy 2020:8-11: see also Back \& Sinha 2018 on "sociable methods").

We also need to accept that "artistic truth" can sometimes better inform us about the world that we live in than "scientific truth", but in arts-based work, it is probably better to conceptualise it as "truthfulness" (Leavy 2020:287). Bauman and Mazzeo (2016:8) argue that we need to read literary works and sociology texts since they "correct each other's occupational blunders". In the case of The mental states of Gothenburg, I find that it contains scenes that communicate the living conditions of young people in a manner that affects the audience in ways that no sociological publication ever could. Leavy underlines how arts-based research is often consumed in ways that promote empathy (Leavy 2020:25; cf. Djikic, Oatley \& Moldoveanu 2013 for a problematisation of such claims). In an interview in the podcast Scenpodden (2019), Andersson argues that even when he uses documentary material, theatre always involves some form of enhancement of that material: "Reality is not unrequited, so to speak, but it is still elevated and embodied in the performing arts. The important thing then is that it feels true" (cf. Leavy 2020:287). This entails a certain balancing act, however. In her discussion on using art in research presentations, Gunaratnam (2007:282) warns against the "aestheticization of suffering". There is also an interesting tension between 
Andersson's reasoning here and his emphasis on what percentage of the manuscript was made up of extracts from the transcripts. The one character that I felt that he could have "listened" more carefully to was a middle-class girl who candidly reflected on her privileges and her struggle to find a purpose in life in the interview, but was portrayed as defensive and spoiled on stage. The ambivalent claim to authenticity and the inherent tension between aesthetics, politics, and ethics in documentary theatre are topics worthy of further research (Arlid 2021).

\section{The value of the sociological craft}

Before I handed in my first transcript from an interview with a young man from one of the deprived suburbs of Gothenburg, Andersson was worried whether nine interviews would provide enough material for his project. However, when he had read the transcript, he got in touch with me and said that he was utterly overwhelmed. He thought that he would be able to write an entire play based only on this young man's tale (it was him that I described as the "star" of the play above). People who are critical of collaborative work between sociology and the arts sometimes object to such projects on the grounds that the sociologist's analyses run the risk of being downgraded and not seen as scientifically significant. In her comment on Nisbet's view on sociology as an art form, Judith Adler (2015:317) warns against relaxing demands regarding empirical verification, especially in times when qualitative research is under an ideologically motivated attack. Nisbet's (1967) portrayal of the ideal sociologist resembles that of the "genius artist" (Connell 1997), but what Mills (1967[1959]) and Back (2007) suggest is not for sociologists to become artists or novelists. Rather, they argue for the unique contributions that sociologists can offer. It is no coincidence that they both describe sociology in terms of a craft; the sociology that they promote is not to be understood as a shortcut but as a lifelong commitment to arduous work.

I am a trained sociologist, not an artist. I see great potential in collaboration with non-academics and in arts-based methods approaches, but just like sociology, art is a craft that needs to be cultivated and respected. The mental states of Gothenburg affected me in a way that a sociological analysis of the same interviews could not have. Performances are not read; they are experienced, Leavy (2008:344) claims. In his comparison between artists and sociologists, Becker (2007:30-33) discusses how the sociologist tries to control the reader while the artist enjoys the freedom of leaving their work open to a variety of interpretations. However, there is of course also great value to be found in academic studies where the reader gets to know how the author, after working in the field for several years, interpreted the stories of the study's participants with reference to previous research and with the help of theoretical concepts (cf. Mills (1967[1959]):18).

When Leavy (2020:273-301) discusses evaluation criteria for arts-based research, she draws from previous work in both fields. Generally, the criteria for evaluating art and the social sciences are different, and rightly so (cf. Edling and Rydgren 2015:12). However, much of the literature on the relationship between the arts and sociology clearly shows the problematic nature of evaluating qualitative research using procedures 
created to evaluate quantitative studies. Nevertheless, these scholars do not offer any alternative models for this undertaking, thus making Adler's critique of Nisbet generally more relevant to the present conversation. For example, when I lecture on urban ethnography at university, I often refer to Sarah Tracy's (2010) list of "big tent" criteria for ensuring quality in qualitative research as a starting point. This list promotes elaborative, imaginative, and transparent work and is not tied to epistemology and ontology, hence the "big tent" metaphor. The aim of Tracy's work is twofold; she offers students a pedagogical tool that is of use to their learning about qualitative research, but she also provides researchers in the social sciences with a clearly articulated set of standards to address the value of qualitative studies in the context of applying for funding and in public outreach initiatives (ibid.:39-40). The sociology that Mills and Back argue for will undoubtedly pass such a review. Theatre plays, novels, and photographic exhibitions would not, however, even if "the sociological" were positioned at the centre of the artist's work.

Continuous collegial conversation around ethical issues that emerge during all stages of the research process is an integrated part of the sociological craft (Back 2007:98). In the present article I argue that this is one of the reasons why we have much to contribute in collaborations with artists who use qualitative methods. A serious commitment to these issues was a prerequisite for my participation in Andersson's projects. In contrast to the remarks above, his methodologically well-reasoned work would doubtless do quite well against Tracy's criteria and probably even better against Leavy's. However, for artists like Andersson, following academic guidelines on ethics is a voluntary choice, not the obligation that it is for sociologists involved in arts-based research (Arlid 2021:55). Lastly, it should be noted that failing tests such as Tracy's does not entail that such sociologically-informed art cannot, as Benson (2018) argues, be used to "trouble [the] boundaries" of our discipline and challenge us to communicate our findings in forms that enable us to reach a wider audience. We definitely need criteria of the kind that Tracy offers, but we must always be aware of the risks that slavishly following such a list may entail, even if it aims to be "inclusive". As both Mills (1967[1959]:122) and Nisbet (1976:7) remind us, some of the classic sociological publications that are most frequently referred to by other scholars are also somewhat speculative in nature, which is part of the very reason why such work has so much influence over the field. To use Bauman as an example, the value of his sociological craft cannot be confined to mere evaluation of whether metaphors such as solidlliquid modernity and the touristlthe vagabond are the result of systematic empirical investigations (Jacobsen \& Marshman 2008; for further discussions on creative theorising in the social sciences, see Swedberg 2014). 


\section{Concluding discussion}

Watching "the sociologist" as a character in the stage play The mental states of Gothenburg was a formative experience for me. Reading and reflecting on Nisbet's (1967:4) critique of "scientism" while taking to heart Mills' (1967[1959]:217-222) appeal that we avoid "socspeak" and Leavy's (2020:xiv) call to represent our research in different shapes helped me more precisely identify what is at stake in discussions of the relationship between sociology and the arts. Refusing to play the role of "the sociologist" comes with its own risks, as Adler's critique of Nisbet points out. In the past decade, an evidence-based movement has argued that critical qualitative research is of little value for social policy and should not receive public funding (e.g. Denzin 2019). In recent debates in Sweden, research in the humanities (and, to some extent, in the social sciences) has been criticised in a similar vein for being based on personal opinions and not living up to basic scientific standards. For example, instead of research aiming to "change society", Göran Larsson (2019:50), a Swedish historian of religion, wants to see "robust explanations and theories of how the world is constituted". In this article, I have argued against such solutions. One strength of arts-based research is how it promotes public scholarship and serves the immediate communities where it is conducted. Consequently, it has the potential to result in very useful work (Leavy 2020:28). The first piece of advice that Back (2007:173) offers his PhD students is to trust their own interests. This does not, however, mean that they should merely confirm their own political opinions. The very formulation of a research project can be motivated as an intervention for something that needs to be addressed (Back \& Hall 2009:663); although the intervention proper may, of course, be implemented in some distant future, depending on the research findings.

In his discussion of politics, Mills argues that the sociologist is responsible for taking part in public debate. He underlines "the political task of the social scientist - as of any liberal educator - continually to translate private troubles into public issues, and public issues into the terms of their human meaning for a variety of individuals" (Mills 1967[1959]:184-87). In his call for counterfactual imagination, Paulsen (2014:182) underlines the importance of not taking capitalism for granted. The complex reasons behind many of the private troubles of our time cannot be found in individual mistakes and shortcomings, which is something that needs to be emphasised in this phase of neo-liberalism organised around an ethos of punishment (Davies 2017[2015]). Linking together biography and history will not provide us with objective answers and causal explanations. However, I am convinced that such endeavours can open up conversations that allow us to understand our present better and to mobilise ourselves to imagine and actualise different political futures. As stated above, refusing to play the role of "the sociologist" comes with its own set of risks, but so too does playing this role. If our goal is to reach a wider audience, we might, as Mills suggests, have to lose the "academic pose" and trust our arguments (1967[1959]:219-220, see also Leavy 2020:1-2).

Back's concept of "sociological listening" bears many similarities to Mills' "sociological imagination". However, writing in a context where the tabloid press and social 
media are ubiquitous, he argues that the value of sociology lies in its time-consuming practice. This gives us a unique opportunity to challenge the ways in which the meaning of certain "problems" is claimed by journalists and opinion-formers (Back 2007:20). Artists can rarely work on projects over such long periods of time. Following Benson's (2018) advice that we should not dismiss "the sociological" that is found in the work of non-academic narrators of society — such as The mental states of Gothenburg - out of fear that it might make our work seem "unscientific", does not entail a downgrading of the sociological craft. In this article, I have countered this potential criticism by arguing that it is in collaborative work with artists who, like us, "tell about society" that the sociological craft can be further cultivated and realise its potential to make well-founded interventions, both in academic discussions and in public conversations.

\section{Acknowledgements}

The author would like to thank her colleagues Catharina Thörn, Mattias Wahlström, Christel Backman, Karl Malmqvist and Hannah Jones, and the audiences at her presentations at the Sociological Review conference "Undisciplining: Conversation from the edges" (18-21 June 2018) and at Högre seminariet at the Department of Literature, History of Ideas and Religion, University of Gothenburg (16 October 2019) for valuable comments on early versions of the paper. She is also indebted to the anonymous reviewers and the editors who helped to improve the arguments substantially.

\section{References}

Adler, J. (2015) "Caritas and community: Reflections of the conservative sociological art of Robert Nisbet”, Sociology 52 (3):316-323. https://doi.org/10.1007/s12115-015-9907-1

Arlid, J. (2021) "Att vara verklighetens tolk: Estetik, politik och gestaltning i dokumentär scenkonst”. Master's thesis. Göteborg: Department of Cultural Sciences, University of Gothenburg.

Back, L. (2007) The art of listening. Oxford: Berg Publishers.

Back, L. \& S. Hall (2009) "At home and not at home: Stuart Hall in conversation with Les Back", Cultural Studies 23 (4):658-687. https://doi. org/10.1080/09502380902950963

Back, L. \& S. Sinha, with C. Bryan, V. Baraku \& M. Yemba (2018) Migrant city. London: Routledge. https://doi.org/10.4324/9781315881850

Bassel, L. (2017) The politics of listening: Possibilities and challenges for democratic life. London: Palgrave. https://doi.org/10.1057/978-1-137-53167-4

Barone, T. \& E. Eisner (2012) Arts based research. London: Sage.

Bauman, Z., M. Jacobsen \& K. Tester (2016) What use is sociology? Cambridge: Polity Press. Bauman, Z. \& R. Mazzeo (2016) In praise of literature. Cambridge: Polity Press.

BBC News (2011) "London riots: Boris Johnson faces angry business owners", 9 August 2011, http://www.bbc.co.uk/news/uk-politics-14464579 (Accessed 31 August 2021). 
Becker, H. (2007) Telling about society. Chicago: University of Chicago Press.

Benson, M. (2018) "Stating the sociological: An introduction", The Sociological Review, 30 October 2018, https:/www.thesociologicalreview.com/stating-the-sociological/ (Accessed 31 August 2021).

Berger, M. (1977) Real and imagined worlds: The novel and social science. Cambridge: Harvard University Press. https://doi.org/10.4159/harvard.9780674418998

Billig, M. (2013) Learn to write badly. Cambridge: Cambridge University Press. https:// doi.org/10.1017/CBO9781139208833

Bourdieu, P. et al. (1999[1993]) The weight of the world: Social suffering in contemporary society. Stanford: Stanford University Press.

Brown, W. (2015) Undoing the demos: Neoliberalism's stealth revolution. New York: Zone Books.

Brown, W. (2019) In the ruins of neoliberalism: The rise of antidemocratic politics in the West. New York: Colombia University Press.

Butler, J. (2009) Frames of war: When is life grievable? New York: Verso.

Calvino, I. (1986) The uses of literature. San Diego: Harcourt Brace.

Carrington, B. (2017) "Publicising the personal, privatising the public: Rethinking the social through Mills and Hall", keynote at the British Sociological Association annual conference 4-6 April 2017, Manchester. Transcript online: https://www. britsoc.co.uk/resource-library/resource-view/?id=421 (Accessed 31 August 2021).

Connell, R.W. (1997) "Why is classical theory classical?", American Journal of Sociology 102 (6):1511-1557. https://doi.org/10.1086/231125

Davies, W. (2017[2015]) The limits of neoliberalism: Authority, sovereignty and the logic of competition. London: Sage.

Denzin, N. (2019) The qualitative manifesto: A call to arms. New York: Routledge. https://doi.org/10.4324/9780429449987

Dikeç, M. (2018) Urban rage: The revolt of the excluded. New Haven: Yale University Press.

Djikic, M., K. Oatley \& M. Moldoveanu (2013) "Reading other minds: Effects of literature on empathy”, The Scientific Study of Literature 3 (1):28-47. https://doi. org/10.1075/ssol.3.1.06dji

Duneier, M. (2002) "What kind of combat sport is sociology?", American Journal of Sociology 107 (6):1551-1576. https://doi.org/10.1086/342925

Edling, C. \& J. Rydgren (2011) Sociological insights of great thinkers: Sociology through literature, philosophy, and science. West Port: Praeger.

Edling, C. \& J. Rydgren (2015) Sociologi genom litteratur: Skönlitteraturens möjligheter och samhällsvetenskapens begränsningar. Lund: Arkiv.

Erel, U., T. Reynolds \& E. Kaptani (2017) "Participatory theatre for transformative research", Qualitative Research 17 (3): 302-312. https://doi. org/10.1177/1468794117696029

Forser, T. (2015) "Platsens teater och mentala tillstånd", 259-273 in M. Andersson (Ed.) United states of Sweden. Stockholm: Atlas.

Foster, V. (2016) Collaborative arts-based research for social justice. London: Routledge. https://doi.org/10.4324/9780203077450 
Gunaratnam, Y. (2007) "Where is the love? Art, aesthetics and research", Journal of Social Work Practice 21 (3):271-287. https://doi.org/10.1080/02650530701553518

Halsey, A.H. (2004) A history of sociology in Britain: Science, literature, and society. Oxford: Oxford University Press. https://doi.org/10.1093/0199266603.001.0001

Hesse-Biber, S.N. \& P. Leavy (Eds.) (2008) Handbook of emergent methods. New York: Guilford Press.

Hilton, J. (2015) "Intervju med Mattias Andersson", 303-326 in M. Andersson (Ed.) United states of Sweden. Stockholm: Atlas.

Hilton, J. (2019) “DN tipsar: 70 kulturhändelser du inte får missa i höst”, Dagens Nyheter, 21 August 2019.

Jacobsen, M. \& S. Marshman (2008) “Bauman's metaphors: The poetic imagination in sociology", Current Sociology 56 (5):798-818. https://doi. org/10.1177/0011392108093836

Kaptani, E. \& N. Yuval-Davis (2008) "Participatory theatre as a research methodology: Identity, performance and social action among refugees”, Sociological Research Online 13 (5):1-12. https://doi.org/10.5153/sro.1789

Knowles, G. \& A. Cole (Eds.) (2008) Handbook of the arts in qualitative research: Perspectives, methodologies, examples, and issues. London: Sage.

Larsson, G. (2019) Humaniora - en vetenskap som andra. Stockholm: Timbro.

Leavy, P. (2008) "Performance-based emergent methods", 343-357 in S.N. HesseBiber \& P. Leavy (Eds.) Handbook of emergent methods. New York: Guilford Press.

Leavy, P. (2020) Method meets art: Arts-based research practice. New York: Guilford Press.

Lepenies, W. (1988[1985]) Between literature and science: The rise of sociology. Cambridge: Cambridge University Press.

Liamputtong, P. \& J. Rumbold (Eds.) (2008) Knowing differently: Arts-based and collaborative research methods. New York: Nova Science Publishers.

Malmqvist, K. (2017) “Edling, Christofer \& Rydgren, Jens (Eds.) 2016. Sociologi genom litteratur. Skönlitteraturens möjligheter och samhällsvetenskapens begränsningar” [book review], Statsvetenskaplig tidskrift 119 (2):346-349.

Marander-Eklund, L. \& A.C. Östman (Eds.) (2011) Biografiska betydelser. Norm och erfarenhet i levnadsberättelser. Möklinta: Gidlunds förlag.

Mills, C.W. (1967[1959]) The sociological imagination. Oxford: Oxford University Press.

Mulinari, D. (2003), lecture cited in H. Wikström (2007) (O)möjliga positioner. PhD dissertation. Gothenburg: Department of Social Work, University of Gothenburg.

Nader, L. (1972) "Up the anthropologist: Perspectives gained from studying up", 284311, in D. Hymes (Ed.) Reinventing anthropology. New York: Vintage.

Nisbet, R. (1976) Sociology as an art form. Portsmouth: Heinemann Educational Books Ltd. https://doi.org/10.4324/9781315129990

Paulsen, R. (2014) “The counterfactual imagination”, 164-182 in R. Swedberg (Ed.) Theorizing in social science: The context of discovery. Stanford: Stanford University Press.

Puwar, N. \& S. Sharma (2012) "Curating sociology", The Sociological Review 60 (1):40-63. https://doi.org/10.1111/j.1467-954X.2012.02116.x 
Reed Ariail, I. \& M. Zald (2014) "The unsettlement of communities of inquiry", 95-114 in R. Swedberg (Ed.) Theorizing in social science: The context of discovery. Stanford: Stanford University Press.

Saldaña, J. (2016) Ethnotheatre: Research from page to stage. London: Routledge.

Scenpodden (2019) “\#49 Dokumentärteater - med Mattias Andersson”, 12 April 2019, https://soundcloud.com/scenpodden/49-dokumentarteater-med-mattias-andersson (Accessed 31 August 2021).

Slater, T. (2011) "From 'criminality' to marginality: Rioting against a broken state", Human Geography 4 (3):106-115. https://doi.org/10.1177/194277861100400307

Swedberg, R. (Ed.) (2014) Theorizing in social science: The context of discovery. Stanford: Stanford University Press.

The mental states of Gothenburg (2006) Screenwriter and director: Mattias Andersson. Angereds Teater.

The mental states of Sweden (2013) Screenwriter and director: Mattias Andersson. Dramaten.

Törnqvist, M. (2016) “Sociologi som konstform”, Sociologisk Forskning 53 (3):307-315. Tracy, S.J. (2010) “Qualitative quality: Eight 'big-tent' criteria for excellent qualitative research", Qualitative Inquiry 16 (10):837-851. https://doi. org/10.1177/1077800410383121

Utopia 2012 (2012) Screenwriter and director: Mattias Andersson. Backa Teater.

Vetenskapsrådet (2002) "Forskningsetiska principer inom humanistisk-samhällsvetenskaplig forskning”. Stockholm: Vetenskapsrådet.

Wacquant, L. (2002) "Scrutinizing the street: Poverty, morality and the pitfalls of urban ethnography”, American Journal of Sociology 107 (6):1468-1532. https://doi. org/10.1086/340461

Weber, M. (1946[1919]) "Science as a vocation", 129-157 in H.H. Gerths \& C.W. Mills (Eds.) From Max Weber: Essays in sociology (1991[1948]). London: Routledge. https://doi.org/10.4324/9780203452196

\section{Author}

Helena Holgersson has a $\mathrm{PhD}$ in Sociology and works as a senior lecturer at the Department of Cultural Sciences, University of Gothenburg. Her current research focuses on gentrification and performing arts history from a social perspective. She is a partner in the EUTOPIA learning unit Creative Research Methods.

\section{Corresponding author}

Helena Holgersson

Department of Cultural Sciences, University of Gothenburg

Box 200, 40530 Gothenburg

helena.holgersson@gu.se 